\title{
Takhrij Hadis : Analisis Kritik Matan dan Sanad Hadis Rukyat
}

\author{
Mhd. Fikri Maulana Nasution
}

Uinpmh.fikrimedan@gmail.com

\begin{abstract}
Abstrak
Rukyat menjadi salah satu metode dalam menentukan masuknya awal bulan baru dalam kalender Islam. Pelaksanaan rukyat juga didasarkan pada hadis nabi, dalam pencarian hadis tentang rukyat itu dan mengetahui keberadaan hadis beserta sanadnya digunakanlah metode takhrij hadis, sehingga difahami bahwa status para perawi yang meriwayatkan hadis yang berkaitan dengan rukyat tersebut, dan juga status hadis rukyat tersebut. Dari penelitian ini maka dapat dipastikan bahwa para perawi yang siqah dan hadisnya sahih dan dapat dijadikan landasan dalam hukum Islam.
\end{abstract}

Kata kunci : Rukyat, haidis, hukum Islam

\section{A. Pendahuluan}

Rukyat menjadi salah satu tema yang selalu mencuat ketika masuk dalam pembahasan penentuan awal bulan kamariah, tarik ulur metode yang diterapkan baik itu rukyat atau hisab.

Banyak hadis yang memuat tentang penentuan awal bulan kamariah, khususnya Ramadan, Syawal,dan Zulhijah, dari banyak hadis yang ada pada makalah ini fokus kepada hadis berikut:

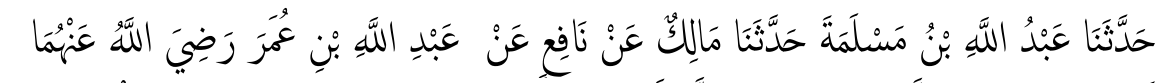

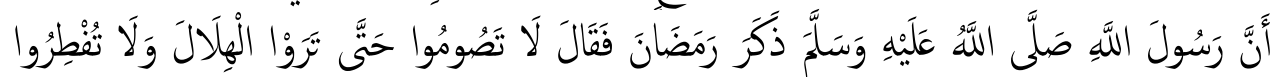

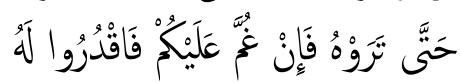

Telah menceritakan kepada kami 'Abdullah bin Maslamah telah menceritakan kepada kami Malik dari Nafi' dari 'Abdullah bin 'Umar radliallahu 'anhu bahwa Rasulullah shallallahu 'alaihi wasallam menceritakan tentang bulan Ramadhan lalu Beliau bersabda: "Janganlah kalian berpuasa hingga kalian melihat hilal dan jangan pula kalian berbuka hingga kalian melihatnya. Apabila kalian terhalang oleh awan maka perkirakanlah jumlahnya (jumlah hari disempurnakan)".

Karena mengingat pentingnya menilai kedudukan sanad hadis dalam suatu periwayatan, sehingga hadis tersebut bisa diterima atau tertolak, maka disini akan dilakukan analisis kritik yang lebih mendalam terhadap sanad dan rawi hadis tentang seputar rukyat melalui metode takhrij. Bagaimana status hadis nabi yang berkaitan dengan rukyat? dan apakah Nabi pernah menggunakan metode hisab ?. 


\section{A. Definisi Takhrij Hadis}

Kata takhrij (تخريج) adalah masadar dari wazan (خرج- يخرج-تخريج) yang memiliki makna "mengeluarkan sesuatu dari tempatnya" kata takhrij memiliki arti al-Zuhur (tanpak) atau al-buruz (jelas), selain itu bisa juga diterjemahkan sebagai al-istinbat (kesimpulan), al-tadrib (meneliti) dan at-taujuh (menerangkan). ${ }^{1}$

Sedangkan para ahli hadis mendefinisikan takhrij hadis sebagai berikut :

Mahmud al-Thahhan :

Takhrij adalah (usaha) menunjukkan letak asal hadis pada sumbersumbernya yang asli yang didalamnya telah dicantumkan sanad hadis tersebut (secara lengkap), serta menjelaskan kualitas hadis tersebut jika kolekter memandang perlu. ${ }^{2}$

Nawir Yuslem :

Hakekat takhrij adalah penelusuran atau pencaraian hadis pada berbagai kitab hadis sebagai sumbernya yang asli yang didalamnya dikemukakan secara lengkap matan dan sanad Hadis. ${ }^{3}$

M. Syuhudi Isma'il :

Takhrij Hadis adalah penelusuran atau pencaraian Hadis pada berbagai kitab sumber asli dari hadis yang bersangkutan, yang didalam seumber itu dikemukakan secara lengkap matan dan sanad hadis yang bersangkutan. ${ }^{4}$ Selanjutnya Syuhudi Isma'il membagi takhrij hadis dalam dua bagain yakni $^{5}$ :

1. Takhrij al-Hadis bi al-Alfaz

Yakni upaya pencarian hadis pada kitab-kitab hadis dengan cara menelusuri lafas hadis yang dicari

2. Takhrij al-Hadis bi al-Maudu'

Yakni upaya pencarian hadis berdasarkan pada tema dari suatu hadis.

Dari beberapa penjelasan diatas maka dapat ditarik kesimpulan bahwa pencarian dan menelusuran hadis kepada sumber aslinya untuk mendapatkan secara lengkap baik itu sanad maupun matan dari hadis yang dicari.

\section{B. Urgensi Takhrij Hadis}

${ }^{1}$ Lihat : Louis Ma'luf, al-munjid fi al-Lughah wa al-Alam, (dar al-Masyriq), hlm. 172. Ahmad Warson Munawwir, Kamus al-Munawwir (Surabaya:Penerbit Progresif, 1984) : 333.

${ }^{2}$ Mahmud al-Thahhan, Ushul al - Takhrij Wa dirasatu al - Asanid, (Riyadh, Maktabah alMa'arif, 1978),: 10

${ }^{3}$ Nawir Yuslem, Ulumul Hadis , (Jakarta: Mutiara Sumber Widya, 1997), : 395. 1992),: 43

${ }^{4}$ M. Syuhudi Isma' il, Metodalogi Penelitian Hadis Nabi, (Jakarata, Bulan Bintang,

${ }^{5}$ M. Syuhudi Ismail, Cara Praktis Mencari Hadis, ( Jakarta : Bulan Bintang,1991), hlm. 16. 
Ada beberapa hal yang menyebabkan pentingnya kegiatan takhrij hadis, di antaranya adalah :

1. Mengetahui asal usul riwayat hadis yang akan diteliti suatu hadis akan sangat sulit diteliti status dan kualitasnya apabila tidak diketahui asal usul hadis. Untuk mengetahui bagaimana asal-usul hadis yang akan diteliti itu maka kegiatan takhrij perlu dilakukan terlebih dahulu. Dengan demikian, takhrij hadis sangat diperlukan, yaitu untuk melacak bagaimana sanad dan matan hadis dalam kitab sumber. Tanpa diketahui asal usulnya, maka sanad dan matan hadis yang bersangkutan sulit diketahui susunannya menurut sumber pengambilannya. Tanpa diketahui susunan sanad dan matannya secara benar, maka hadis yang bersangkutan akan sulit diteliti secara cermat. ${ }^{6}$

2. Mengetahui seluruh rawi hadis yang akan diteliti mungkin memiliki lebih dari satu sanad. terlebih dahulu harus diketahui seluruh riwayat hadis yang bersangkutan. Dalam hubungannya untuk mengetahui seluruh riwayat hadis yang akan diteliti, Mungkin saja salah satu sanad hadis itu berkualitas da'if, sedang yang lainnya berkualitas sahih. Untuk dapat menentukan sanad yang berkualitas da'if dan yang berkualitas sahih, maka kegiatan takhrij al-hadis perlu dilakukan. ${ }^{7}$

3. Untuk menentukan kualitas suatu Hadis, Ibnu Hajar al-'Asqolani menjelaskan bahwa khabar yang tidak mutawatir dapat dipakai sebagai dasar hukum apabila memenuhi kriteria tertentu . Kriteria tertentu yang telah ditetapkan oleh para pakar hadis ialah adanya kesahihan sanad dan matan hadis, yakni segala syarat atau kriteria yang harus dipenuhi oleh sesuatu sanad dan matan hadis yang berkualitas sahih. ${ }^{8}$

\section{Metode dalam Takhrij Hadis}

Beberapa metode untuk mentakhrij hadis sebagai berikut ${ }^{9}$ :

1. Takhrij Melalui Lafal Yang Terdapat Dalam Matan Hadis

Metode ini diterapkan manakala kita mengetahui suatu matan Hadis baik sebahagian maupun keseluruhan, terletak diawal, ditengah, diakhir atau dibagian mana saja dari Hadis tersebut. Dalam menggunakan metode ini diperiukan kitab kamus hadis. kamus hadis yang cukup lengkap adalah kitab susunan Dr. AJ. Wensinck dan

\footnotetext{
${ }^{6}$ Askolan Lubis, “Urgensi Metodologi Takhrij Hadis Dalam Studi Keislaman” Jurnal Ihya’ al-Arabiyah No. 1 (2016): 17.

${ }^{7}$ Lubis, "Urgensi Metodologi Takhrij,; 18

${ }^{8}$ Lubis, "Urgensi Metodologi Takhrij,.

9 Jon Pamil, "Takhrij Hadis: Langkah Awal Penelitian Hadis" an-Nida : Jurnal Pemikiran Islam No. 1 (2012):55-60
} 
kawan-kawan yang telah diterjemahkan kedalam bahasa Arab oleh Muhammad Fu'ad 'Abdul Baqi dengan judul ( al - Mu'jam al Mufahras li Alfazhi al - Hadis an - Nabawi). Selain itu dibutuhkan juga kitab-kitab hadis yang muktabarah untuk mengetahui hadis yang ingin dicari

2. Takhrij Melalui Lafal Pertama Matan Hadis.

Bila suatu hadis dapat dipastikan bunyi lafal pertamanya, maka diselain mengunakan metode pertama, bisa juga menelusuri hadis dengan menggunakan lafal pertama matan Hadis tersebut. Dalam mempergunakan metode ini ada tiga macam kitab Hadis yang sangat membantu

- Kitab-kitab yang berisi himpunan hadis-hadis yang tersebar luas serta termasyhur ditengah masyarakat

- Kitab-kitab yang menghimpun hadis berdasarkan urutan huruf mu'jam ( hijaiah)

- Kitab-kitab Mafatih dan F'aharis yang dikarang para ulama untuk kitab-kitab induk tertentu.

3. Takhrij Hadis Melalui Perawi Pertama (Para Sahabat Yang Meriwayatkan Hadis)

Banyak dijumpai baik dalam karangan maupun dalam ceramah, suatu hadis yang dikutip biasanya disebutkan perawi pertama sebelum matan Hadis kemudian kolektornya setelah matan hadis atau keduanya diletakkan setelah matan hadis. Kalau dijumpai hadis seperti demikian, maka salah satu cara mentakhrijnya adalah dengan melalui perawi pertama tersebut.

4. Takhrij Melalui Tema-Tema Hadis.

Takhrij Hadis dengan metode ini didasarkan pada pengenalan tema suatu hadis yang ingin ditakhrij. Dengan demikian, maka metode ini hanya efektif digunakan oleh orang yang punya kemampuan dalam mengidentifikasi tema hadis. Dalam menerapkan metode ini tentu saja langkah pertama yang dilakukan seorang pentakhrij adalah menetapkan tema hadis yang akan ditakhrij. Setelah itu barulah menelusuri hadis tersebut baik dengan mempergunakan kamus hadis maupun lansung pada kitab-kitab hadis maupun kitab-kitab lainnya yang menuliskan hadis berdasarkan tema-tema tertentu.

\section{Teori Naqd Hadis dalam Takhrij Hadis}

Secara bahasa al-naqd mempunyai pengertian sama dengan al-tanqad yaitu meneliti seksama, menyatakan secara khusus yang asli dan menyingkirkan yang palsu darinya. Naqd oleh sebagian kalangan diartikan 
sebagai kritik. Dan kata naqd digunakan oleh sebagian ulama hadis awal di abad kedua dengan makna kritik. Metode naqd hadis pada masa Nabi, yaitu melakukan verifikasi atas informasi yang disandarkan kepada Nabi dengan menanyakan langsung kebenarannya kepada $\mathrm{Nabi}^{10}$

Teori Naqd hadis sendiri memiliki dua garis besar yakni ${ }^{11}$ :

1. al-Naqd al-Kharijiyyun (kritik sanad hadis) Pada kaidah al-naqd alkharijiyyun ini membahas tentang cara-cara periwayatan hadits. sahnya periwayatan. keadaan rawi, dan kadar kepercayaan kepada mereka. Kritik pada umumnya berkisar di sekitar persoalan, yaitu ketersambungan sanad dan kesiqahan rawi. Kritik terhadap sanad merupakan penyelidikan terhadap kejujuran rawi menyampaikan sumber hadis didapat. Langkah pertama dalam melakukan penelitian hadis adalah melihat ittisa al-sanad (bersambungnya sanad) sampai pada Rasulullah saw.

2. al-Naqad al-Dâkhili (Kritik Matan Hadis) Bagian ini lebih banyak berbicara hadis itu sendiri. apakah maknanya sahih atau tidak, dan apa jalan-jalan yang dilalui dalam menuju kesahihannya. Metode al-Naqad al-Dakhili hadis pada umumnya melakukan langkah "membandingkan" atau "pertanyaan silang" dan "referensi silang". Langkah teknis metode al-naqad al-dakhili dengan mengumpulkan semua yang berhubungan dengan materi atau informasi, kemudian secara hati-hati membandingkan dengan satu persatu dengan yang lain, satu informasi dinilai keakuratan sumber (rawi).

\section{E. Kritik Sanad dan Matan Hadis Rukyat}

Sebelum masuk pada kritik matan hadis rukyat, dilakukan takhrij hadis terhadap rukyat, sebagaimana pada pendahuluan bahwa hadis rukyat yang dimaksud adalah sebagai berikut :

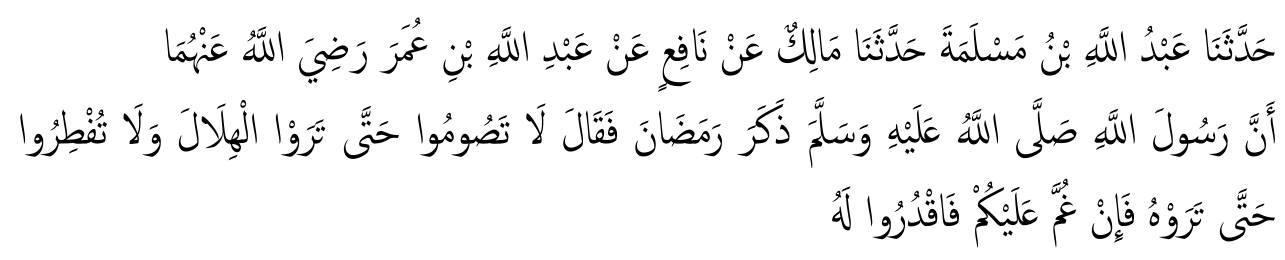

${ }^{10}$ Hatta Abdul Malik, "Naqd Al-Hadits Sebagai Metode Kritik Kredibilitas Informasi Islam” Journal Islamic Studies and Humanities, No.1 (2016) : 58

11 M. Hasbi Ash-Shiddieqy, Sejarah \& Pengantar Ilmu Hadits (Semarang: Pustaka Rizki Putra, 2009), 279-280 
Jika hadis ini ditakhrij menggunakan metode pertama maka seorang yang ingin men-takhrij bisa mengambilsalah satu dari kata yang ada pada matan hadis, matan sendiri di mulai dari فاقدروا له sampai dengan لا تصومو dalam tulisan ini Takhrij menggunakan metode ini dan kata yang diambil adalah لا تصوموا dan kata فاقدرواله

Jika hadis ini ditakhrij menggunakan metode kedua dengan mengetahui lafaz pertama dari matan hadis, maka seorang harus mengambil kata $\gamma$ تصوموا sebagai awal dari redaksi hadis.

Dari segi sanad, jika ingin mentakhij dengan metode ketiga maka seseorang harus mengetahui sahabat yang meriwayatkan hadis, pada hadis ابن عمر رضي الله عنهما diatas perawi pertama (pada tingkat sahabat)

Jika mengunakan metode keempat, maka seorang pentakhrij harus bisa menyimpulkan apa tema suatu hadis, dan tema hadis ini adalah rukyat.

Setelah melakukan takhrij maka hadis diatas terdapat pada S\{ahih alBukhari> karangan Muhammad bin Ismail al-Bukhari, Nomor Hadis 1807, Kitab As\}-S\}iyam dalam Bab Qaul an-Nabi Iz\}a Raitum al-Hilal Fas\{umu wa Iza Raaitumuhu Fa Aftiru.

Selain pada kitab tersebut, hadis dapat juga di temukan dalam beberapa kitab sebagai berikut ;

- Riwayat Muslim, dalam kitab Shahih Muslim- Kitab as-SiyamNo. Hadis 2080 :

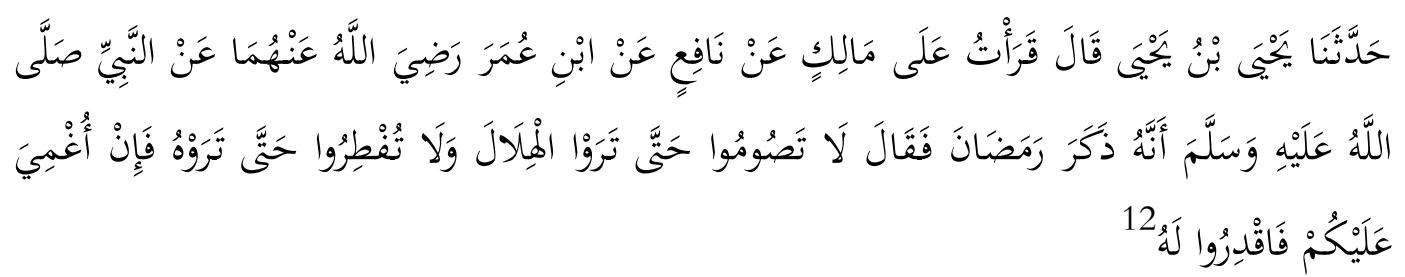

Telah menceritakan kepada kami Yahya bin Yahya ia berkata, saya telah membacakan kepada Malik dari Nafi' dari Ibnu Umar radliallahu 'anhu dari Nabi shallallahu 'alaihi wasallam, bahwa beliau menyebutkan Ramadlan, dan beliau pun bersabda: "Janganlah kalian berpuasa hingga kalian melihat Hilal (bulan

${ }^{12}$ Muslim bin Hajjaj, S\}ahih Muslim, (Beirut, Dar al-Fikr, 1992), I:481, Kita>b Słiyam, No. Hadis 1799. 
sabit) dan jangan pula berbuka(beridul fitri) hingga melihatnya (terbit) kembali. Namun, jika bulan itu tertutup dari pandanganmu, maka perkirakanlah."

- Riwayat An-Nasai, dalam Kita>b al-S \}iyam, Ba>b Zakara alIkhtila $>\mathrm{f}$ 'Ala al-Z>ahri> fi> haz|a Hadis, No. Hadis 6117.

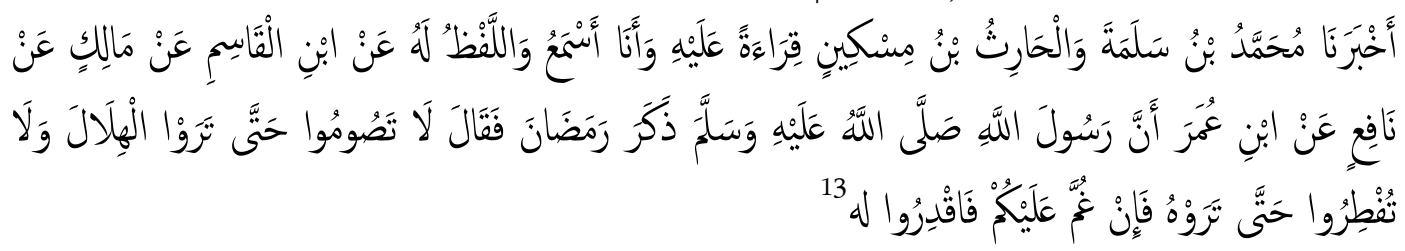

Telah mengabarkan kepada kami Muhammad bin Sa'd dan Al Harits bin Miskin secara baca, dan Aku mendengarnya, lafazh ini miliknya, dari Ibnul Qasim dari Malik dari Nafi' dari Ibnu 'Umar bahwa Rasulullah shallallahu 'alaihi wasallam menyebutkan Ramadlan, lalu bersabda: "'Janganlah kalian berpuasa hingga kalian melihat Hilal (bulan sabit) dan jangan pula berbuka(beridul fitri) hingga melihatnya (terbit) kembali. Namun, jika bulan itu tertutup dari pandanganmu, maka perkirakanlah."

- Riwayat Ahmad bin Hambal, Kita>b Takmilah Musnad 'Abdullah bin 'Umar bin al-Khatta>b, No. Hadis 5694.

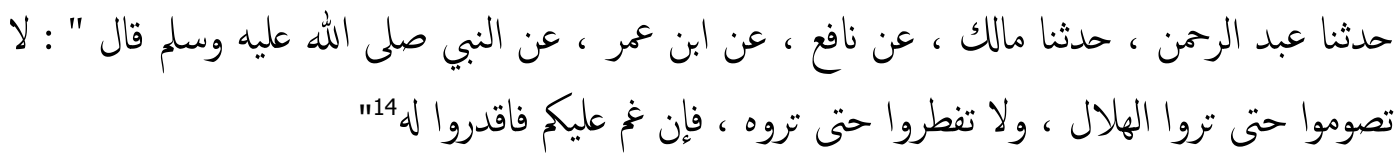

Telah menceritakan kepada kami Abdurrahman, Menceritakan kepada kami Malik, dari Nafi' dari Ibnu Umar dari Nabi "Janganlah kalian berpuasa hingga kalian melihat Hilal (bulan sabit) dan jangan pula berbuka(beridul fitri) hingga melihatnya (terbit) kembali. Namun, jika bulan itu tertutup dari pandanganmu, maka perkirakanlah."

- Riwayat Malik, Kita>b S\{iyam, bab Ma>Ja>’a fi> Rukyat alHila>l wa al-Aftiru fi $>$ Ramad $\} a>n$, No. Hadis : 234.

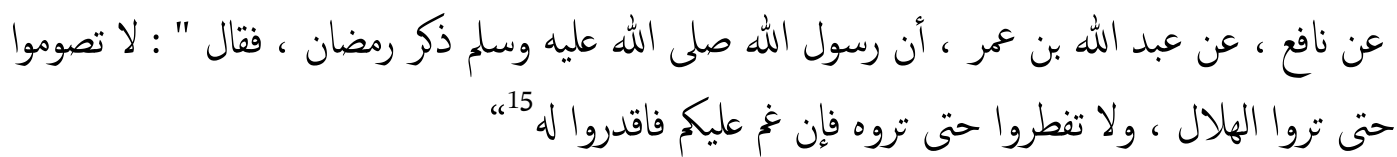

dari Nafi' dari Abdullah bin Umar, bahwa Rasulullah shallallahu 'alaihi wasallam sedang membahas tentang Ramadan. Beliau bersabda: "Janganlah

${ }^{13}$ Abi $>$ Abdurrahman Ahmad bin Shu'ub an-Nasa'i, Sunan an-Nasa'i, (Beirut : Dar alFikr, 2009), II : 137, Kita>b al-S \}iyam, Ba>b Zakara al-Ikhtila $>$ ' ‘Ala al-Z>ahri> fi> haz|a Hadis, No. Hadis 6117.

${ }^{14}$ Ahmad bin Muhammad bin Hambal, al-Musnad, (Cairo : Da>r al-Hadi $>$ s, 2012) IV:107, Kita>b Takmilah Musnad 'Abdullah bin 'Umar bin al-Khatta >b, No. Hadis 5694.

${ }^{15}$ Ma>lik bin Anas, al-Muwatha' al-Imam Ma>lik, (Beirut : Dar al-Kutb al-'Ala $>$ miyah, 2009):145, Kita $>b$ S\{iyam, bab Ma> Ja>'a fi> Rukyat al-Hila >l wa al-Aftiru fi $>$ Ramad $\} a>n$, No. Hadis : 234. 
kalian berpuasa hingga kalian melihat Hilal (bulan sabit) dan jangan pula berbuka(beridul fitri) hingga melihatnya (terbit) kembali. Namun, jika bulan itu tertutup dari pandanganmu, maka perkirakanlah."

- Riwayat ad-Darimi, dalam Kita>b al-S\{aum, $b a>b$ as-S\{aum li rukyat al-Hilal, no. Hadis 1586.

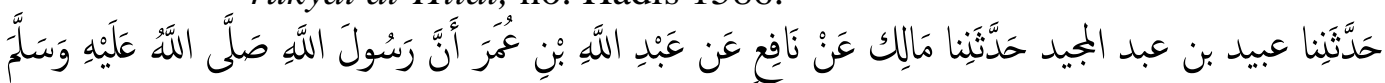

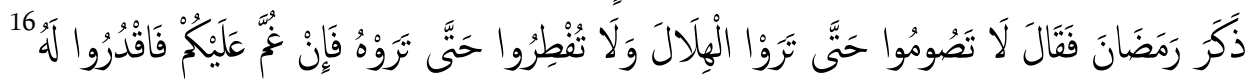

Telah menceritakan kepadaku Yahya dari Malik dari Nafi' dari Abdullah bin Umar, bahwa Rasulullah shallallahu 'alaihi wasallam sedang membahas tentang Ramadan. Beliau bersabda: "Janganlah kalian berpuasa hingga kalian melihat Hilal (bulan sabit) dan jangan pula berbuka(beridul fitri) hingga melihatnya (terbit) kembali. Namun, jika bulan itu tertutup dari pandanganmu, maka perkirakanlah."

\section{Kritik Sanad Hadis}

Sebelum jauh pada kritik sanad hadis, maka struktur hadis ini sebagai berikut

16 Abi $>$ 'Abdullah bin Bahra $>$ m ad-Darimi, Sunan ad-Da>rimi>, (Beirut: Dar alFikr,2005) : II : 3. Kita >b al-S\{aum, ba>b as-S\{aum li rukyat al-Hilal, no. Hadis 1586. 


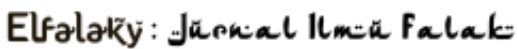

\section{Rangkaian Sanad Hadis Rukyat}

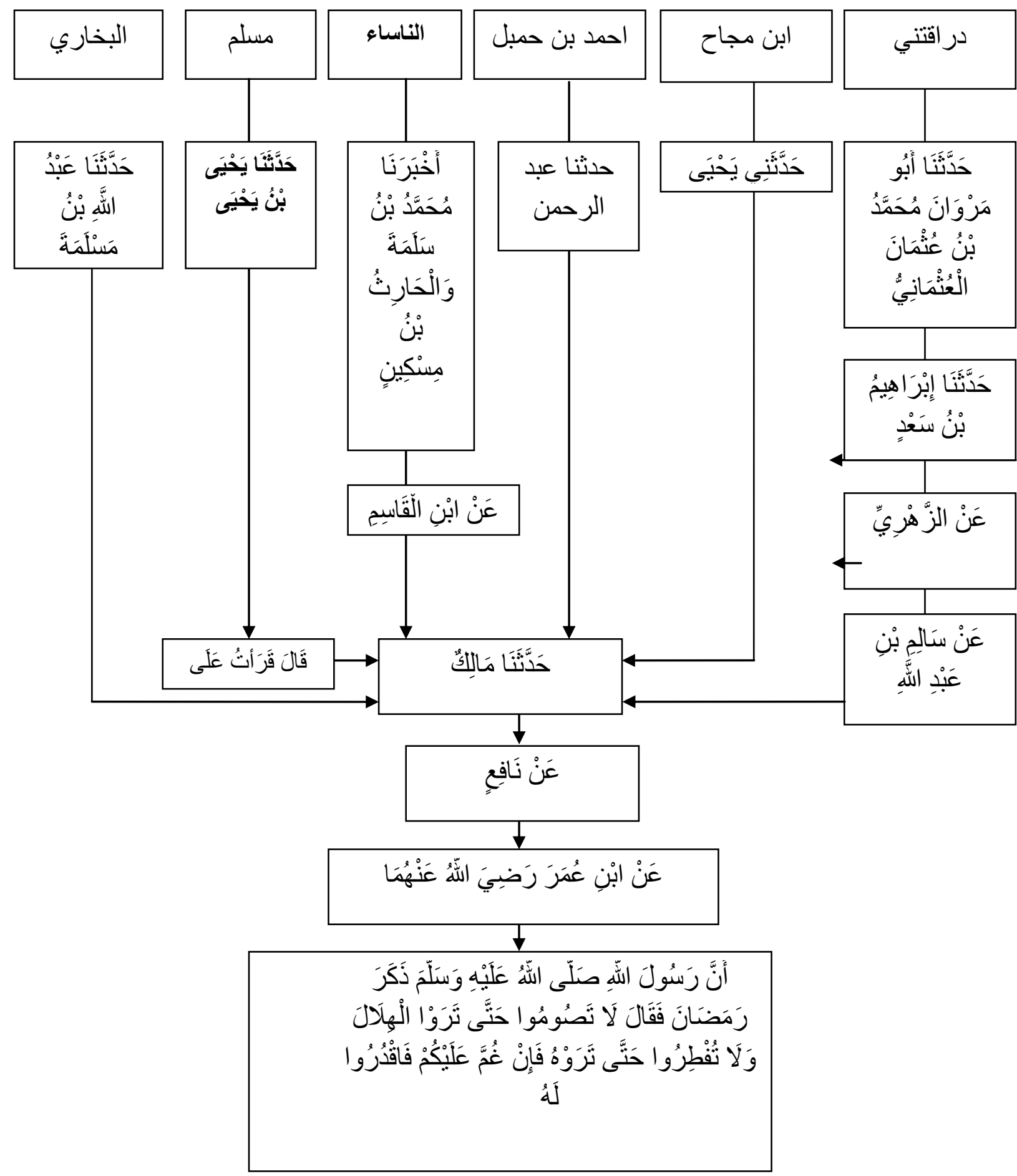




\section{Telaah Rijal al-Hadis (Perawi Hadis)}

\section{Hadis Riwayat Bukhari}

\section{- Abdullah bin Maslamah}

Nama lengkapnya Abdullah bin Maslamah bin Qa'nab wafat di Mekah pada bulan Muharram $220 \mathrm{H}$, didalam tahzi> $b$ al-tahzi $>b$ fi> rija>l al-Hadi>s dinayatakan bahwa Ibnu Maslamah adalah perawi yang siqah. ${ }^{17}$

- Malik

Nama lengkapnya adalah Malik bin Anas bin Malik bin 'Amir bin bin Amri bin Haris bin Ghiman bin Jusail bin Amur bin Haris, wafat pada bulan Safar $179 \mathrm{H}$. ulama mengkatagorikan beliau sebagai perawi yang Siqah ${ }^{18}$

- Nafi'

digelar dengan Nafi' al Faqih, nafi' merupakan pembantu Abdullah bin Umar, wafat pada tahun $117 \mathrm{H}$, para ulama menghukumi beliau siqah. $^{19}$

\section{- Ibnu Umar}

Nama lengkapnya Abdullah bin Umar bin al-Khattab bin Nuqail alQurasy al-'Adawi, wafat pada $73 \mathrm{H}$. beliau juga digolongkan sahabat yang banyak meriwatakan hadis, dan banyak para ulama yang memuji keilmuannya ${ }^{20}$

Nama-Nama Perawi yang sudah di jelaskan pada sub bab ini, tidak dibahas lagi jika ada kesamaan perawi dalam hadis berikutnya.

\section{Hadis Riwayat Muslim}

\section{- Yahya bin Yahya}

Nama lengkapnya Yahya bin Yahya bin Bukr bin Abdurrahman bin Yahya bin Hammad at-Tamimi al hamsholi atau Abu Zakaria an-Naisaburi, belau wafat pada $226 \mathrm{H}$, Imam Nasa' I mengatakan belau perawi yang siqah. $^{21}$

\section{Hadis Riwayat An-Nasa'i}

- Muummab bin Salamah

Muhammad bin Salamah bin Abdullah bin Abi Fatimah al-Muradi al Jamali,Wafat pada Rabiul Akhir pada 448 H, beliau merupakan perawi siqah siqah. ${ }^{22}$

\section{Al-Haris bin Miskin}

Nama lengkapnya al-Haris bin Miskin bin Muhammad bin Yusuf al Umari.lahir pada $154 \mathrm{H}$ dan wafat pada Rabiul Akhir $250 \mathrm{H}$,

17 Shihab al-Din Abi Fadl Ahmad bin Ali bin Muhammad Ibnu Hajar al-'Asqollani, tahzi $>b$ al-tahzi $>b$ fi $>$ rija $>$ l al-Hadi $>s$, ( Beirut : Dar al-Kutb al-Ilmiyah, 2004) III: 662

${ }^{18}$ Asqollani, tahzi $>b$ al-tahzi $>b$ fi $>$ rija $>l$, VI:137

${ }^{19}$ Asqollani, tahzi $>b$ al-tahzi $>b$ fi $>$ rija $>l$, VI:523

${ }^{20}$ Asqollani, tahzi $>b$ al-tahzi $>b$ fi $>$ rija $>l$, III:579

${ }^{21}$ Asqollani, tahzi $>b$ al-tahzi $>b$ fi $>$ rija $>l$, VII:121,

${ }^{22}$ Asqollani, tahzi $>$ b al-tahzi $>b$ fi $>$ rija $>l, \mathrm{~V}: 608$. 
beliau siqah menurut an-Nasa'I, al-Khatib, al-Hakim dan Maslamah al-Andalusi ${ }^{23}$

\section{- Ibnu Qosim}

Abdurrahman bin al-Qasim bin Khalid bin Jundah al-'Utaqi termasuk orang yang lama berguru kepada Malik, lahir pada $67 \mathrm{H}$ dan wafat $161 \mathrm{H}$. An-Nasa'i, al-Hakim, al-Khatib, dan Abu Zu'ah mengatakan bahwa Ibnu Qosim adalah Siqah. ${ }^{24}$

\section{Hadis Riwayat Ahmad Bin Hambal}

\section{- Abdurrahman}

Nama lengkapnya Abdurrahman bin Mahdi bin Hasan bin Abdurrahman al-'Anbari, wafat pada 198 H, Ibnu Said dan Abu Hatim menggolongkannya siqah. ${ }^{25}$

\section{Hadis Riwayat ad-Darimi}

- Ubaidillah bin Abdul Majid

Nama lengkapnya Ubaidillah bin Abdul Majid, wafat pada 209 H, ad-darimi sendiri mengomentari Laisa Bihi Bakst ${ }^{26}$

Dalam rantaian sanad pada pembahasan diatas ada beberapa kata yang digunakan oleh para perawi seperti :

حَنَّنًَا (Telah menceritakan kepada kami) atau أَخْبَرَنَ (Telah mengabarkan kepada Kami): beberapa ulama mengganggap bahwa sama dengan memeberikan keterangan bahwa guru hadis menyampaikan langsung kepada periwayat yang mengeluarkan hadis terserbut. ${ }^{27}$ Beberapa hadis menggunakan redaksi حَنَّنَا / أَخْبَرَنَا yang memiliki kekuatan bahwa para perawi sebelumnya menyampaikan langsung kepada rawi setelahnya

عَ (Dari) : kata ini menunjukkan bahwa hadis diterima dengan cara di dengar/sama', beberapa syarat yang di detapkan adalah dalam sanad yang mengandung عَ itu tidak ditemukan penyembuan infomasi yang dilakukan oleh periwayat. Antara periwayat dimungkinkan bertemu. ${ }^{28}$ Dalam hadis diatas penerimaan hadis dengan lafas $َ$ dari Ibnu Umar kepada Nafi', dan dari Nafi' kepada Malik, dalam paparan rijalul hadis, Ibnu Umar dengan dengan Nafi' saling bertemu karena Nafi' adalah pembantu Ibnu Umar, dan dari tahun kewafatan di mungkinan Nafi' bertemu dengan Malik.

قَرَأَتُ عَلَى (Aku membaca dihadapan) : kata-kata ini menunjukkan periwayat yang menerima membaca sendiri di depan guru hadisnya. ${ }^{29} \mathrm{Hal}$ ini yang terdapat dalam sanad hadis yang diriwayatkan oleh Muslim. Dari

59.

${ }^{23}$ Asqollani, tahzi>b al-tahzi $>b$ fi $>$ rija $>l, \mathrm{I}: 625$.

${ }^{24}$ Asqollani, tahzi $>b$ al-tahzi $>b$ fi $>$ rija $>l$, IV:115.

${ }^{25}$ Asqollani, tahzi $>b$ al-tahzi $>b$ fi $>$ rija $>l$, IV:139.

${ }^{26}$ Asqollani, tahzi $>b$ al-tahzi $>b$ fi $>$ rija $>l$, IV:133.

${ }^{27}$ M. Syuhudi Isma'il, Kaedah Kesahihan Sanad Hadis, (Jakarta:Bulan Bintang, 1995):

\footnotetext{
${ }^{28}$ Isma'il, Kaedah Kesahihan Sanad.

${ }^{29}$ Isma'il, Kaedah Kesahihan Sanad: 62.
} 
rangkaian ini maka semua periwayat hadis rukyat dapat dipastikan para perawinya langsung bertemu satu sama lain.

Kaidah yang digunakan dalam kritik hadis pertama kaidah mayor; dan kedua kaidah minor. Sebagai berikut ${ }^{30}$ :

(a) sanadnya bersambung,

Kaidah minor dari sanad bersambung adalah muttasil, marfu>' dan mahfu>z.

(b) periwayatnya bersifat adil,

Kaidah minor dari periwayat bersifat adil adalah beragama Islam, mukallaf, melaksanakan ketentuan agama, dan memelihara wibawa atau harga diri.

(c) periwayatnya bersifat dabit,

Kaidah minor dari periwayat yang bersifat dabit adalah hafal dengan baik hadis yang diriwayatkannya, mampu dengan baik menyampaikan hadis yang dihafalnya kepada orang lain

Dari rangakaian dan penelusuran sanad bahwa hadis diriwayatkan oleh para perawi merupakan orang yang mencukupi kaidah-kaidah yang disebutkan oleh Syuhudi Ismail, sehingga hadis ini dapat diterima.

\section{Kritik Matan Hadis}

Hadis dapar dikatakan diterima matannya jika hadis tersebut lolos dari dua syarat yakni Syaz yakni secara bahasa dimaknai sebagai jarang, menyendiri, asing, menyalahi aturan, Syafi'I berpendapat bahwa dinyatakan hadis itu tidak syaz jika diriwayatkan oleh periwayat yang siqah namun, tidak diriwayatkan oleh periwayat lain, dinyatakan syaz jika hadis yang di riwayatkan oleh pewari siqah namun bertentangan dengan periwayat yang lebih siqah. ${ }^{31}$ Dan tidak adanya 'Illat yang secara bahasa dimaknai sebagai cacat atau kesalahan baca, dalam istilah hadis dimaknai sebagai sesuatu yang tersembunyi yang dapat merusak kualitas hadis. ${ }^{32}$

Akhir hadis ini memiliki dua redaksi, redaksi pertama seperti hadis yang dikemukakan dengan lafaz فاقدروا له dan lafaz yang lain menggunakan

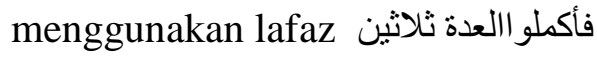

Hadis ini memeliki dua redaksi yang mirip dengan hadis diatas yang sama-sama di riwayatkan oleh Ibnu Umar, redaksiya sebagai berikut :

Dan hadis berikut

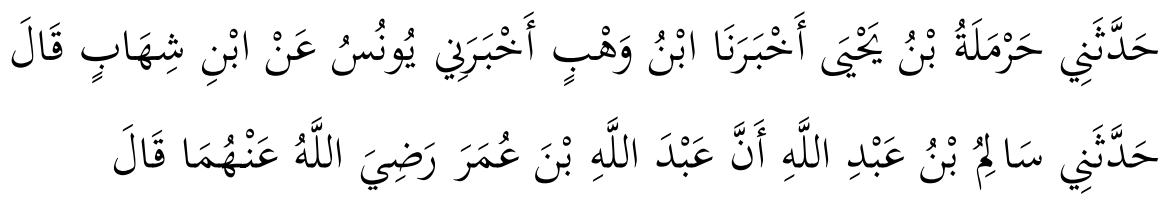

${ }^{30}$ Ismail, Kaedah Kesahihan Sanad Hadis,: 120.

31 Okteberiansyah, dkk, al-Hadis, (Yogyakrta : Pokja Akademik UIN Sunan Kalijaga, 2005), 116

${ }^{32}$ Okteberiansyah, dkk, al-Hadis, : 117. 


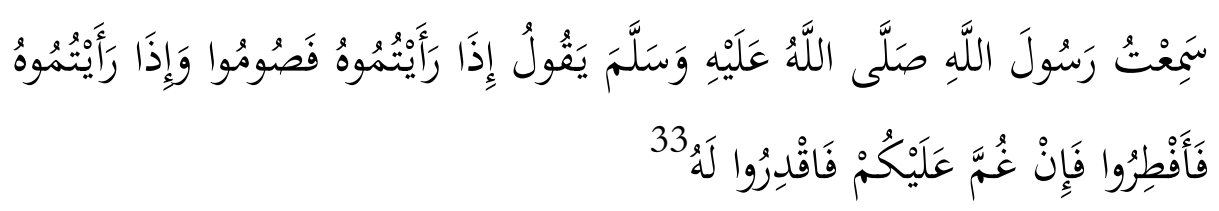

Telah menceritakan kepadaku Harmalah bin Yahya telah mengabarkan kepada kami Ibnu Wahb telah mengabarkan kepadaku Yunus dari Ibnu Syihab ia berkata, telah menceritakan kepadaku Salim bin Abdullah bahwa Abdullah bin Umar radliallahu 'anhuma berkata; Saya mendengar Rasulullah shallallahu 'alaihi wasallam bersabda: "Jika kalian melihat HIlal, maka berpuasalah dan jika kalian melihatnya (terbit) kembali, maka berbukalah, namun bila ia tertutup dari pandanga kalian, maka hitunglah (bilangan harinya)."

Selain hadis yang langsung berkaitan dengan rukyat, ada hadis yang secara tidak langsung penggunaan rukyat dan penyebabnya :

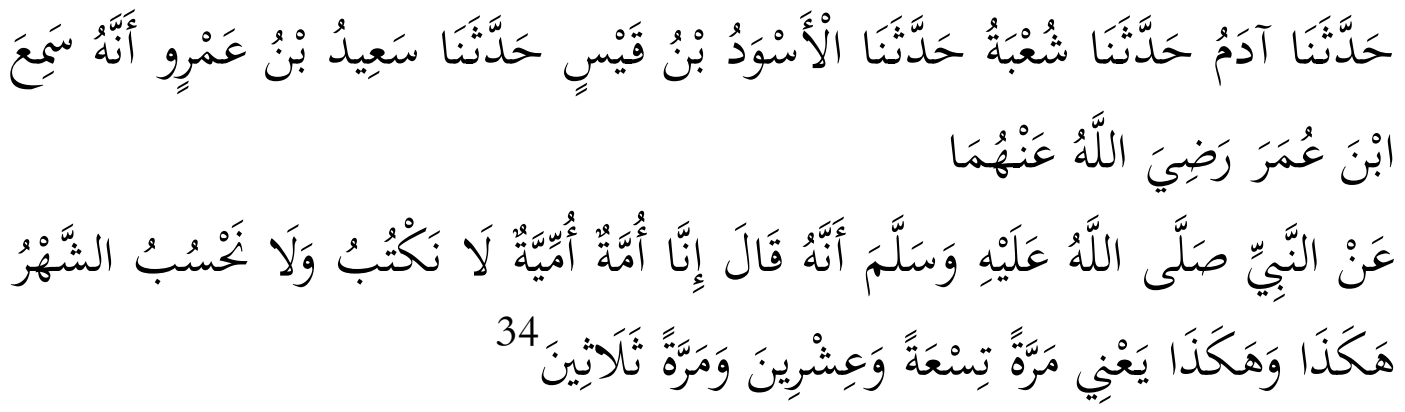

Telah menceritakan kepada kami Adam telah menceritakan kepada kami Syu'bah telah menceritakan kepada kami Al Aswad bin Qais telah menceritakan kepada kami Sa'id bin 'Amru bahwa dia mendengar Ibnu'Umar radliallahu 'anhuma dari Nabi shallallahu 'alaihi wasallam bersabda: "Kita ini adalah ummat yang ummi, yang tidak biasa menulis dan juga tidak menghitung satu bulan itu jumlah harinya segini dan segini, yaitu sekali berjumlah dua puluh sembilan dan sekali berikutnya tiga puluh hari".

Samsul Anwar berpendapat bahwa ungkapan "la naktubu wa la nahsubu" dengan menggunakan huruf nun di depannya yang diartikan sebagai kata kami yang maksudnya adalah masyarakat muslim pada masa nabi yang kebanyakan diantara mereka yang tidak bisa menulis dan yang dimaksud dengan hisab adalah perhitungan perbintangan dan peredaran. ${ }^{35}$

\footnotetext{
${ }^{33}$ Muslim bin Hajjaj, S \}ahih Muslim, (Beirut, Dar al-Fikr, 1992), I:481, Kita>b S \}iyam, No. Hadis 1080.

${ }^{34}$ Muhammad bin Ismail al-Bukhari, Sahih Bukhari, (Beirut:Dar al-Kutub al-Ilmiyah, 2006), I: 281, Kita>b S \}iyam, No. Hadis 1913.

35 Syamsul Anwar, Interkoneksi Studi Hadis dan Astronomi, (Yogyakarta: Suara Muhammadiyah, 2011), hlm.187.
} 
Asy-Suyuti berpendapat bahwa Faqdiru>lah maknanya adalah hitungan secara benar hari bulan syakban dan menggenapkannya 30 hari. Hal senada di ungkapkan oleh al-Sindi yang menyatakan bahwa Faqdiru>lah memiliki makna menggenapkan hitungannya menjadi tiga puluh hari. ${ }^{36}$

Walapun terdapat perbedaan dalam redaksi hadis, namun tidak ada pertentangan yang jelas dalam lafaz-lafaz hadis hal ini juga dilihat dari nilai para perawi yang meriwayatkannya pada bahasan sebelumnya. Sehingga hadis ini dapat diterima untuk dijadikan dasar dalam mengambil keputusan.

\section{F. Penutup}

Dari paparan diatas maka difahami bahwa takhij hadis sangat penting dalam memulai penelitian hadis, dari studi takhrij hadisnya lahirnya kritik hadis yang dilakukan guna untuk memilah dan memilih mana hadis yang dianggap dapat diterima untuk dijadikan pondasi-pondasi hukum Islam. Begitu juga dengan takhrij yang dilakukan terhadap hadis rukyat pada pembahasan adalah hadis shahih yakni shahih lidzatihi karena sanadnya bersambung (muttasil), para rawinya dhabit dan tsiqah, terhindar dari syuzuz, dan jika dilihat dari jarh wa ta"dilnya para perawi mereka adil, shaduq dan tsiqah. Kondisi masyarakat arab yang terbatas pengetahuannya maka pada zaman nabi tidak pernah ada atau di peraktekkan metode hisab.

\section{Daftar Pustaka}

\section{Buku}

Anwar, Syamsul, Interkoneksi Studi Hadis dan Astronomi, Yogyakarta: Suara Muhammadiyah, 2011.

Asqollani, Shihab al-Din Abi Fadl Ahmad bin Ali bin Muhammad Ibnu Hajar al', tahzi $>$ b al-tahzi $>$ b fi $>$ rija $>$ l al-Hadi $>$ s Jilid I, Beirut : Dar al-Kutb alIlmiyah, 2004.

Dar al-Kutb al-Ilmiyah, 2004. , tahzi $>$ b al-tahzi $>$ b fi $>$ rija $>$ l al-Hadi $>$ s Jilid IV, Beirut :

Dar al-Kutb al-Ilmiyah, 2004.

Dar al-Kutb al-Ilmiyah, 2004. , tahzi $>$ b al-tahzi $>$ b fi> rija $>$ l al-Hadi $>$ s Jilid VII, Beirut :

Dar al-Kutb al-Ilmiyah, 2004.

Bukhari, Muhammad bin Ismail al-, Sahih Bukhari, Beirut:Dar al-Kutub alIlmiyah, 2006.

Hajjaj, Muslim bin, Słahih Muslim Jilid I, Beirut, Dar al-Fikr, 1992.

${ }^{36}$ Jala>luddin as-Suyuti, Sunan an-Nasa'i bi Syarh, Sunan an-Nasa' $i$, (Beirut : Dar alFikr, 2009), II : 136. 
Isma' il, M. Syuhudi, Metodalogi Penelitian Hadis Nabi, Jakarata, Bulan Bintang, 1992.

Ismail, M. Syuhudi, Cara Praktis Mencari Hadis, Jakarta : Bulan Bintang,1991.

Ismail Syuhudi, Kaidah - Kaidah Kesahihan Sanad Hadis, Jakarta: Bulan Bintang, 1995.

Ma'luf, Louis, al-munjid fi al-Lughah wa al-Alam,(dar al-Masyriq.

Munawwir, Ahmad Warson, Kamus al-Munawwir Yogyakarta:

Thahhan, Mahmud al-, Ushul al - Takhrij Wa dirasatu al - Asanid, Riyadh, Maktabah al-Ma'arif, 1978.

Shiddieqy, M. Hasbi Ash- Sejarah \& Pengantar Ilmu Hadits Semarang: Pustaka Rizki Putra, 2009.

Yuslem, Nawir, Ulumul Hadis, Jakarta: Mutiara Sumber Widya, 1997.

Okteberiansyah, dkk, al-Hadis, Yogyakrta : Pokja Akademik UIN Sunan Kalijaga, 2005.

Jurnal

Askolan Lubis, "Urgensi Metodologi Takhrij Hadis Dalam Studi Keislaman" Jurnal Ihya' al-Arabiyah No. 1 (2016).

Jon Pamil, "Takhrij Hadis: Langkah Awal Penelitian Hadis" an-Nida : Jurnal Pemikiran Islam No. 1 (2012)

Hatta Abdul Malik, "Naqd Al-Hadits Sebagai Metode Kritik Kredibilitas Informasi Islam” Journal Islamic Studies and Humanities, No.1 (2016) 